\title{
AFINAL, O QUE É GÊNERO EM COMUNICAÇÃO? O CONSUMO DA PROGRAMAÇÃO MIDIÁTICA TELEVISIVA.
}

\author{
AFTER ALL, WHAT IS GENRE IN COMMUNICATION?
}

THE CONSUMPTION OF TELEVISION PROGRAMS.

\begin{abstract}
DiANA GUALBERTO DE MACEDO
Mestre em Comunicação e Práticas de Consumo pela Escola Superior de Propaganda e Marketing e graduada em Comunicação Social - Publicidade e Propaganda pela Universidade Federal do Paraná. E-mail: dianagmacedo@hotmail.com.

MARIA APARECIDA BACCEGA

Docente do programa de Mestrado em Comunicação e Práticas de Consumo pela Escola Superior de Propaganda e Marketing e livre docente em Comunicação pela

Universidade de São Paulo.
\end{abstract}

\section{RESUMO}

Pretende-se neste artigo refletir sobre o conceito de gênero no campo da comunicação e, pensar sobre ele enquanto propulsor do consumo midiático televisivo, principalmente com relação ao consumo dos programas que circulam na televisão. Destacar-se-á, no decorrer do artigo, a importância dos gêneros enquanto mediadores do processo comunicacional, que por sua vez envolve tanto emissores/produtores, quanto receptores/consumidores. Além disso, abordar-se-á sobre a relação dos gêneros com os estereótipos, ou seja, ao mesmo tempo em que organizam o pensamento do sujeito, limitam a sua visão. $E$, essa limitação, ou "ultrageneralização necessária", nas palavras de Agnes Heller (1972), pode acabar se "transformando" num preconceito, porém nem sempre deve ser vista como algo negativo.

Palavras-chave: Comunicação. Consumo. Gênero. Programação televisiva.

\section{ABSTRACT}

In this article we expect to reflect about the concept of genre in the field of communication and to think about it as a promoter of television consumption, especially about its programs. Throughout the article we will see the importance of the genres as mediators of the communication process, which involves senders/producers and receptors/ consumers. In addition, we will discuss about the relation between genres and stereotypes, which means, at the same time they organize our thoughts they limit our vision. And this limitation, or "necessary ultrageneralization" in the words of Agnes Heller, may "end up" as a prejudice, but not always it should be seen as something negative. Keywords: Communication. Consumption. Genres. Television time slot. 
Em se tratando de comunicação e consumo, ou melhor, da relação entre ambos, acredita-se que a temática dos gêneros tem um papel importante. Pensar nos gêneros, enquanto estratégia de comunicação dos produtores/ emissores, sob a perspectiva dos programas televisivos como promotores do consumo cultural de televisão, enriquece a reflexão.

Antes de falar sobre o conceito de gênero e seus desdobramentos, faz-se necessário destacar, brevemente, através da citação de Arlindo Machado (2005), a importância de se pensar essa temática relacionada ao consumo dos programas televisivos. Para o autor é somente através dos programas televisivos que se concebe a televisão como um conjunto de elementos:

Creio que já é tempo de pensar a televisão fora desse maniqueismo do modelo ou da estrutura 'boa'ou 'má' em si. Quero dizer: é preciso (também) pensar a televisão como o conjunto dos trabalhos audiovisuais (variados, desiguais, contraditórios) que a constituem, assim como cinema é o conjunto de todos os filmes produzidos e literatura o conjunto de todas as obras literárias escritas ou oralizadas [...]. $O$ contexto, a estrutura externa, a base tecnológica também contam, é claro, mas eles não explicam nada se não estiverem referidos àquilo que mobiliza tanto produtores quanto telespectadores: as imagens e os sons que constituem a 'mensagem' televisual. (grifo nosso, MACHADO, Arlindo, 2005, p.19).

A partir dessa perspectiva, a intenção, ao longo do texto, é discutir a temática dos gêneros, pensando principalmente no telejornal e na telenovela, a linguagem de cada um, bem como a expectativa do receptor em assistir a esses programas (ideia anterior do programa devido às suas especificidades), e as representações de um tipo ideal de consumidor (o destinatário das mensagens

\section{Gênero: a ultrageneralização necessária}

Segundo Agnes Heller há duas maneiras possíveis de ultrageneralização: "por um lado, assumimos estereótipos, analogias e esquemas já elaborados; por outro, eles nos são "impingidos" pelo meio em que crescemos [...]." (HELLER, Agnes, 1972, p.44). De uma forma ou de outra ela é necessária na esfera da cotidianidade.

Mas, então, o que seria essa ultrageneralização? Para a autora nada mais do que um juízo provisório, ou uma regra provisória e necessária de comportamento. Para Heller, uma certa dose de conformidade para que o sujeito se oriente em sua vida social é preciso, todavia, não de conformismo. O conformismo seria quando essa ultrageneralização extrapola e atinge esferas da vida não cotidianas, que para ela são as decisões morais e políticas, de caráter individual. (HELLER, Agnes, 1972, p. 46)

Ter estereótipos, de qualquer tipo, ou seja, religioso, artístico, político, dentre outros, e agir levando-os em consideração é cômodo, pois confirma certas ações anteriores do indivíduo e até mesmo o orienta em relação a 
ações futuras. Eles, portanto, são obra da própria integração social. Para pôr fim a eles, seria necessário extinguir, concomitantemente, com tais convicções, como bem explicita Agnes Heller, fazendo uma analogia com um remédio que só cura a enfermidade matando o enfermo. (p.62).

Em seu livro, $O$ cotidiano e a história (1972), a autora utiliza a palavra preconceito, ao invés de estereótipo, mas opta-se por utilizar estereótipo em alguns casos, já que se entende este como algo mais amplo e nem sempre negativo. De qualquer forma, por que aqui é tão importante falar em estereótipos e preconceitos? A maioria dos estereótipos são produtos das classes dominantes. Pode-se pensar na própria mídia como uma esfera dominante que dissemina estereótipos, até mesmo a partir da narrativa do mundo que cria, a partir de um recorte específico.

[...] as classes dominantes desejam manter a coesão de uma estrutura social que lhes beneficia e mobilizar em seu favor inclusive os homens que representam interesses diversos (e até mesmo, em alguns casos, as classes e camadas antagônicas). (HELLER, Agnes, 1972, p.54)

Pode-se fazer uma analogia entre a citação acima e o conceito de hegemonia de Gramsci, que é a criação de um consenso por parte da classe dominante, que faz circular suas ideias, muitas vezes já incorporadas das ideias de demais grupos não dominantes, ou subalternos, como nomeia Gramsci, para se manter no poder. Budag (2008), ainda sobre o conceito de hegemonia, diz que a cultura é um espaço de "diferenças e lutas sociais" (Richard Johnson, 2001) e, segundo a autora, essa luta ocorre também no campo da linguagem: "cada grupo busca o estabelecimento do sentido que mais o favorece. [...] E esta luta se desenvolve no sentido de a classe dominante tentar fazer prevalecer apenas um significado a determinado signo."

Essas ideias dominantes que circulam na mídia, influenciam a maneira que se assiste a um programa, seja de cunho informativo, como o telejornal ou uma ficção, como a telenovela. E isso ocorre justamente devido ao gênero dos programas. E, por que é tão difícil definir o que é gênero, para o campo da comunicação? Para Jost “'[...] os gêneros estão longe de ser objetos estáticos e estáveis, entidades sem história; [...] sua estruturação não poderia ser concebida à imagem de uma cartografia estabelecida de uma vez por todas." (2004, p.42). Aqui pode-se pensar na programação televisiva especificamente, deve-se falar em gênero? Formatos? Formas? Subgêneros? Categorias? Enfim, esta dificuldade se fez presente ao pesquisar autores que abordavam o mesmo tema. O fato é que as próprias emissoras de televisão não sabem bem ao certo como definir seus programas.

A Rede Globo, por exemplo, em seu site na internet, elenca do lado esquerdo da página dez itens $^{1}$, são eles: novelas, filmes, variedades, séries, humor, jornalismo, auditório, educação, infantil e esportes. Ao clicar sobre qualquer um deles aparecem os programas que os compõem. O 
programa Domingão do Faustão, por exemplo, faz parte de dois desses itens: variedades e auditório; assim como $A$ grande família, que aparece nos itens: séries e humor, A turma do Didi em humor e infantil, dentre outros.

A Rede Record apresenta oito itens no topo da sua página na internet: jornalismo, novelas, variedades, shows, humor, reality, séries e interatividade. O Programa do Gugu, que muito se assemelha ao Domingão do Faustão, faz parte do item shows, por exemplo.

A partir daí, conclui-se que é difícil enquadrar programas em determinadas categorias, até mesmo porque deve-se levar em consideração o hibridismo dos gêneros, cada vez mais característico da contemporaneidade. $\mathrm{O}$ telejornal não apenas informa como entretém, e a telenovela não só entretém como também informa e educa, por exemplo. "Em suma, qualquer que seja a categoria de um programa de televisão, ele deve sempre entreter e pode também informar. Pode ser informativo, mas deve também ser de entretenimento." (ARONCHI DE SOUZA, J.C, 2004, p.39).

Ora os gêneros servem para identificar objetos/produtos com características semelhantes - textos, discursos, programas - ora para dialogar mais especificamente com certas emoções, sendo tratados assim como: drama, comédia, suspense. Reside aí a dificuldade em classificar os gêneros e formatos televisivos, haja vista que, uma hora telenovela é gênero, outra é formato, porque o gênero da telenovela é drama ou comédia romântica ${ }^{2}$, ou ainda melodrama, por exemplo.
A dificuldade consiste, ainda, em separar o gênero ficcional do não ficcional. Em se tratando da linguagem televisiva, existe uma certa indistinção de fronteiras. $\mathrm{O}$ gênero não ficcional utiliza-se sempre de um recorte da realidade - ele apresenta um mundo editado, através de imagens planas na tela, câmeras que fazem cortes a todos os momentos, enquadramentos diversos, entre outros. Dessa forma, embora fale de acontecimentos do mundo, o gênero não ficcional constitui-se também de representações, ou seja, de realidades editadas. Por outro lado, o gênero ficcional, ao buscar a verossimilhança e uma certa coerência interna, acaba por se aproximar bastante da realidade concreta e objetiva, abordando temáticas próprias do cotidiano dos sujeitos, por exemplo: quando uma telenovela serve de pretexto para debates sociais, como se acompanhou na telenovela das 21h da Rede Globo - Viver a Vida - de Manoel Carlos, sobre a questão da tetraplegia (personagem Luciana - representada por Alinne Moraes) $)^{3}$. A diferença está no fato de que não "cobramos" a "verdade" da ficção, ou seja, compreende-se e concede-se a liberdade dos autores de criar e inventar personagens, discursos, lugares, enfim. De qualquer forma, a primeira tarefa do telespectador, mesmo que inconscientemente, é distinguir entre o real e o não real. Segundo Jost, o nome gênero é responsável por "fixar o grau de existência do mundo submetido ao leitor ou ao espectador." (2004, p.32).

Embora haja essa dificuldade de nomenclatura, o que interessa mais de perto aqui é pensar o gê-
2 Drama e comédia romântica são dois gêneros classificados pelo OBITEL - Observatório Ibero-Americano de Ficção Televisiva, em relação à telenovela brasileira.

3 No Brasil, a autora Glória Perez também é conhecida por esse tipo de proposta. "A marca de Glória Perez em suas novelas é a preocupação com questões sociais levadas ao grande público: barriga de aluguel, transplante de órgãos (De Corpo e Alma), crianças desaparecidas (Explode Coração), clonagem humana e drogas (O Clone), e deficiência visual (América)." TELEDRAMATURGIA. Disponível em: <http://www.teledramaturgia.com.br/perez.htm>. Acesso em: 3 de dez. 2009. 
nero enquanto esfera do reconhecível $^{4}$, compreender a familiaridade, através da qual, o indivíduo se relaciona com grande parte deles, já que o entendimento de um gênero pressupõe a existência de um repertório compartilhado que possibilite o diálogo, de acordo com Bakhtin. (BAKHTIN apud LOPES, et al., 2002, p.251).

$\mathrm{O}$ estudo dos gêneros se desenvolveu primeiramente e, principalmente, no campo da literatura - gêneros épico, lírico, dramático - e, acabou influenciando demais áreas do saber.

Se originariamente a literatura fornece a matriz, hoje em dia os gêneros encontram-se na televisão, cinema, publicidade, prateleiras de video-locadoras e até em certo tipo de jornalismo que se dispõe a trabalhar nas frágeis e nebulosas fronteiras entre documental e ficcional. São comédias, tragédias, melodramas; westerns, musicais, suspense e terror que circulam, imageticamente, pelos campos audiovisuais. Falar em gêneros, portanto, significa dialogar, aqui, com a literatura e com outras manifestações da ficcionalidade contemporânea, principalmente aquelas produzidas pelos meios audiovisuais. (BORELLI, S.H.S., 1995, p. 226).

4 Duarte menciona a existência de uma gramática televisual: "identificamos os gêneros a que pertencem, conhecemos suas normas, suas possibilidades e restrições, suas formas de expressão mais usuais, embora, é claro, esse conhecimento não tenha um caráter formal ou sistemático." (DUARTE, Elizabeth Bastos; CASTRO, Maria Lília Dias de., 2007, p.68).
É importante analisar a importância e a relevância dos gêneros tanto para a produção quanto para a recepção, já que eles se constituem no interior de uma dada cultura, na qual ambos os polos da comunicação se veem envolvidos numa perspectiva processual. Mungioli ressalta que é a noção de gênero "que determinará a in- terpretação do enunciado dentro de parâmetros genéricos fundados na comunicação cultural." (MUNGIOLI, 2006, p.43). Isto é, a interpretação é influenciada diretamente pela categorização.

A definição de gênero de Bakhtin é, segundo Machado, a mais aberta e adequada à contemporaneidade, visão da qual compartilha-se:

Para o pensador russo, gênero é uma força aglutinadora e estabilizadora dentro de uma determinada linguagem, um certo modo de organizar ideias, meios e recursos expressivos, suficientemente estratificado numa cultura, de modo a garantir a comunicabilidade dos produtos e a continuidade dessa forma junto às comunidades futuras. Num certo sentido, é o gênero que orienta todo o uso da linguagem no âmbito de um determinado meio, pois é nele que se manifestam as tendências expressivas mais estáveis e mais organizadas da evolução de um meio, acumuladas ao longo de várias gerações de enunciadores. (grifo nosso, MACHADO, 2005, p.68).

E os gêneros tanto orientam a leitura das mensagens e discursos que podem ser considerados importantes mediadores. Os telespectadores/receptores/consumidores sabem o que esperar de um telejornal, de uma telenovela ou de um programa de humor na televisão. Dificilmente ficarão surpresos com a estética da programação midiática. MartínBarbero, (1997, p.299) explica que a própria "dinâmica cultural da televisão atua pelos seus gê- 
neros [...]", alegando existir uma estética da repetição, que trabalha a variação de um idêntico ou a identidade de vários diversos. Para o autor, os gêneros fazem a mediação entre o tempo do capital e o tempo da cotidianidade, eles "constituem uma mediação fundamental entre as lógicas do sistema produtivo e as do sistema de consumo, entre a do formato e a dos modos de ler, dos usos." (p.299). É por essas razões que Martín-Barbero afirma que o gênero é uma "estratégia de comunicabilidade", ele está presente nas mediações, e não no texto.

Analogamente a essa ideia, para o filósofo e linguísta Tzvetan Todorov em seu livro, Os gêneros do discurso (1980), os gêneros funcionam como "horizontes de expectativa" para os leitores e "modelos de escritura" para os autores 5 :

Por um lado, os autores escrevem em função do (o que não quer dizer: de acordo com o) sistema genérico existente (...). Por outro lado, os leitores lêem em função do sistema genérico que conhecem pela crítica, pela escola, pelo sistema de difusão do livro ou simplesmente por ouvir dizer; no entanto, não é necessário que sejam conscientes desse sistema. (TODOROV, T., 1980, p. 49).

É importante ressaltar que pensar os gêneros não tem tão somente o intuito de categorizá-los, mas também, e se diz principalmente, de compreender seu papel como "forma de desenvolvimento cognitivo e estético dos seres humanos." (MUNGIOLI, 2006, p.38). Afinal, como se viu, eles não são categorias fixas no tempo e espaço. Em outras palavras, eles dependem diretamente da cultura em que ocorre a interação comunicacional entre os sujeitos.

\section{O consumo dos gêneros: 0 destinatário do remetente e a promessa de leitura}

Além da parte da produção dos gêneros, há, igualmente importante, a recepção e o consumo destes. Quando um discurso é proferido, uma mensagem enviada, ou um produto lançado no mercado, eles não o são fortuitamente. Existe sempre um ou mais destinatários a quem o(s) remetente(s) se dirige(m). Traçando aqui um paralelo com as cartas, ou, hoje em dia, com os emails, não se consegue enviálos sem ter preenchido o campo do destinatário, ou seja, a pergunta é sempre a mesma: para quem? Seja ela feita pelo carteiro ou pelo próprio computador. E, sem essa informação, a mensagem não será recebida nem o produto consumido.

Não pode haver interlocutor abstrato; não teríamos linguagem comum como tal interlocutor, nem no sentido próprio nem no figurado. Se algumas vezes temos a pretensão de pensar e de exprimir -nos urbi et orbi, na realidade é claro que vemos "a cidade e o mundo" através do prisma do meio social concreto que nos engloba. Na maior parte dos casos, é preciso supor além disso um certo horizonte social definido e estabelecido que determina a criação ideológica do grupo social e da época
5 Mungioli, sobre o mesmo assunto, diz que os gêneros do discurso funcionam como "uma espécie de guia de produção e de interpretação de sentidos." (MUNGIOLI, 2006, p.44.) E Wolf alega que os "gêneros podem funcionar como sistemas de expectativas para os destinatários e como modelos de produção textual para os emissores." (WOLF apud BORELLI, S.H.S, 1995, p.232.) 
a que pertencemos, um horizonte contemporâneo da nossa literatura, da nossa ciência, da nossa moral, do nosso direito. (BAKHTIN, 1988, p.112).

No caso da televisão não é diferente. Cada gênero televisivo tem seus telespectadores. É claro que nem sempre se consegue saber exatamente o perfil deles, mas se tem uma ideia de um telespectador/receptor/consumidor imaginário, ou quem sabe ainda, ideal. Até mesmo porque, cada gênero tem suas especificidades: sua própria linguagem. Há um certo padrão no modo de agir e de vestir dos personagens, horário em que os programas são veiculados, assuntos tratados, duração do programa, entre outras características que permitem sua identificação.

Bakhtin (2003) argumenta que toda compreensão de um enunciado é de natureza responsiva (ativa, embora varie de sujeito para sujeito): "toda compreensão é prenhe de resposta, e nessa ou naquela forma a gera obrigatoriamente: o ouvinte se torna falante. [...] cedo ou tarde, o que foi ouvido e ativamente entendido responde nos discursos subsequentes ou no comportamento do ouvinte." (BAKHTIN, 2003, p.271-272).

Ao falar, sempre levo em conta o fundo aperceptivel da percepção do meu discurso pelo destinatário: até que ponto ele está a par da situação, dispõe de conhecimentos especiais de um dado campo cultural da comunicação; levo em conta as suas concepções e convicções, os seus preconceitos (do meu pon- to de vista), as suas simpatias e antipatias - tudo isso irá determinar a ativa compreensão responsiva do meu enunciado por ele. (BAKHTIN, 2003, p.302).

Os gêneros são necessários para que se perceba e se compreenda o mundo, que por sua vez, se torna cada vez mais complexo. Traça-se, aqui, um paralelo com os estereótipos, como se viu lá no início deste artigo, que por um lado, limitam a visão de mundo, mas por outro, ajudam a organizar fatos, ideias e discursos e, assim, facilitam a interpretação. Para Lippman (1972, p.157), "o abandono de todos os estereótipos por um enfoque totalmente ingênuo da experiência empobreceria a vida humana.". $\mathrm{E}$, se os gêneros do discurso não "existissem e nós não os dominássemos, se tivéssemos de criálos pela primeira vez no processo do discurso, de construir livremente e pela primeira vez cada enunciado, a comunicação discursiva seria quase impossível," (BAKHTIN, 2003, p.283).

Para Bakhtin existem dois grandes gêneros do discurso: primários (mais simples, diálogo oral, íntimo, familiar-cotidiano) e secundários (mais complexos, científicos, literários). São eles, "correias de transmissão entre a história da sociedade e a história da linguagem." (BAKHTIN, 2003, p.268). Para o autor, os discursos pertencem a determinados sujeitos - sujeitos do discurso que os expressam em forma de enunciados.

Em cada enunciado - da réplica monovocal do cotidiano às grandes e complexas obras de 
ciência ou de literatura-abrangemos, interpretamos, sentimos a intenção discursiva de discurso ou a vontade discursiva do falante, que determina o todo do enunciado, o seu volume e as suas fronteiras. Imaginamos o que o falante quer dizer, e com essa ideia verbalizada, essa vontade verbalizada (como a entendemos) é que medimos a conclusibilidade do enunciado. (BAKHTIN, 2003, p.281).

Esses enunciados podem ser entendidos, segundo Eco, tendo em vista um pacto de comunicação, ou como diria Charaudeau, um contrato de comunicação:

O termo contrato de comunicação é empregado pelos semioticistas, psicossociólogos da linguagem e analistas do discurso para designar o que faz com que $o$ ato de comunicação seja reconhecido como válido do ponto de vista do sentido. É a condição para os parceiros de um ato de linguagem se compreenderem minimamente e poderem interagir, co-construindo o sentido, que é a meta essencial de qualquer ato de comunicação. (grifo do autor). (CHARAUDEAU, P.; MAINGUENEAU, D., 2008, p.130).

Este contrato de comunicação garante a previsibilidade dos comportamentos e, como já se viu, oferece, principalmente através dos gêneros, um certo modelo de interpretação. Este conceito é questionado por François Jost. O autor sugere que seja utilizada a noção de promessa ao invés de contrato ou pacto. Isto porque, segundo Jost, os recep- tores - no caso da televisão, os telespectadores - podem não saber da existência desse contrato, afinal segundo o autor, ele não se faz presente nos textos em si, mas sim nos "conhecimentos laterais", ou pode-se dizer: nas mediações: "A promessa não está, pois, no gênero, mas se faz objeto de uma aprendizagem." (JOST, 2004, p.29).

Jost é crítico ainda em relação à nomeação dos gêneros feita pelas emissoras de televisão - o "batismo" de cada programa. Afinal, a classificação dos gêneros tem repercussões econômicas influentes: “[...] para a televisão, o mais importante é saber qual é o gênero que tem maior audiência. [...] são as emissoras que decidem em que categoria ou classificação vão inscrever seus programas." (JOST, F., 2004, p.23). O autor exemplifica citando um exemplo do Conselho Superior do Audiovisual na França:

Na França, como em muitos países da Europa, o Conselho Superior do Audiovisual negocia com os canais e emissoras para autorizar programas, estabelecendo que a televisão, por exemplo, tenha que apresentar 200 horas anuais com programação de ficção. As emissoras, dessa forma, precisam então criar obrigatoriamente 200 horas de programas de ficção por ano. (JOST, 2004, p.21).

A razão econômica, então, seria uma outra razão pela qual existe essa dificuldade em classificar os programas de acordo com gêneros e formatos televisivos, os quais serão abordados de forma mais específica a seguir. 


\section{Gêneros e formatos}

José Carlos Aronchi de Souza em seu livro Gêneros e formatos na televisão brasileira (2004) faz uma divisão entre categorias, gêneros e formatos. Segundo Aronchi, vários formatos podem constituir um gênero, bem como vários gêneros podem formar uma categoria. Segue abaixo desenho ilustrativo do autor:

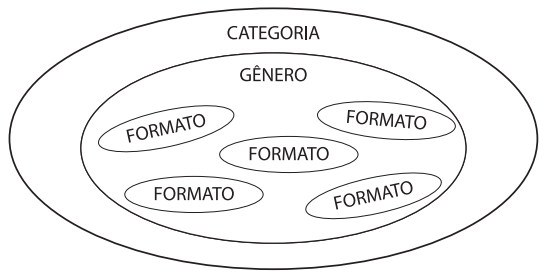

Figura 1 - Categoria, gênero e formato Fonte: José Carlos Aronchi de Souza (2004)

O quadro abaixo também foi elaborado com base no livro do autor, que fez a seguinte classificação:

\begin{tabular}{|l|l|}
\hline CATEGORIA & GÊNERO \\
\hline Entretenimento & $\begin{array}{l}\text { Auditório . Colonismo social . Culinário . Desenho } \\
\text { animado . Docudrama . Esportivo . Filme . Game show } \\
\text { (competição) . Humorístico . Infantil . Interativo . } \\
\text { Musical . Novela . Quiz show (perguntas e respostas) } \\
\text {. Reality show (TV-realidade) . Revista . Série . Série } \\
\text { brasileira . Sitcom (comédia de situações) . Talk } \\
\text { show . Teledramaturgia (ficção) . Variedades . } \\
\text { Western(faroeste) }\end{array}$ \\
\hline Informação & Debate . Documentário . Entrevista. Telejornal \\
\hline Educação & Educativo . Instrutivo \\
\hline Publicidade & Chamada . Filme comercial . Político . Sorteio . \\
\hline Outros & Eelecompra \\
\hline
\end{tabular}

Figura 2 - Categorias e gêneros dos programas na televisão brasileira Fonte: José Carlos Aronchi de Souza (2004)

Tenta-se entender mais sobre essa dinâmica entre gêneros e formatos, quando se pode considerar por gênero modelos mais gerais, e, por formato, a maneira concreta de realização de um programa, ou seja, propriedades mais específicas, ex: ao vivo, videocassetada, video- clipe. Esses gêneros e formatos televisivos se repetem e conformam a estética da televisão - ou estética da repetição, ou como se viu com Martín-Barbero - causando assim uma sensação de familiaridade e segurança, como salienta Rosário:

Visando a uma coletividade de consumidores, o discurso televisivo coloca em circulação formatos determinados e devidamente organizados, reiterando processos de significação e legitimando padrões por meio da repetição. As repetições possibilitam o ordenando e a confirmação de sentidos nos textos, trazendo segurança ao telespectador. (ROSÁRIO, N.M, apud DUARTE, E.; CASTRO, M.L.D, 2007, p.187).

Através das reflexões feitas sobre gênero, a partir dos programas televisivos, pode-se compreender a complexidade e a importância desse tema, que, tal como se viu, originou-se na literatura, mas hoje abarca diversos outros campos, sendo um dos principais o campo da comunicação, que tem na mídia um dos seus principais suportes. A noção de gênero trabalhada aqui, que abarca tanto o lado dos produtores quanto dos consumidores, é a que se considera a mais adequada e a que permitiu traçar esse paralelo com os estereótipos, que não são nem "bons nem ruins". Tanto os estereótipos, quanto os gêneros, limitam a visão do sujeito, mas facilitam a interação e integração social dele, ou, nas palavras de Bakhtin, permitem o "dialogismo", portanto, não devem ser considerados apenas preconceitos, no sentido negativo da palavra. 


\section{Referências}

BAKHTIN, Mikhail. Estética da criação verbal. 4.ed. São Paulo: Martins Fontes, 2003.

BAKHTIN, Mikhail. Marxismo e filosofia da linguagem. São Paulo: Hucitec, 1988.

BORELLI, Silvia Helena Simões. Ação, suspense, emoção: uma antropologia das culturas contemporâneas. Tese de doutorado. PUC-SP. São Paulo, 1995.

BUDAG, Fernanda E. Comunicação, recepção e consumo: suas inter-relações em Rebelde - RBD. Dissertação de mestrado. Escola Superior de Propaganda e Marketing. São Paulo, 2008.

CHARAUDEAU, Patrick; MAINGUENEAU, Dominique. Dicionário de análise do discurso. 2.ed. São Paulo: Contexto, 2008.

DUARTE, Elizabeth Bastos. Programa novo: a gramática televisual levada às ultimas conseqüência. In: DUARTE, Elizabeth Bastos; CASTRO, Maria Lília Dias de. (Orgs.). Televisão: entre o mercado e a academia II. Porto Alegre: Sulina, 2007.

HELlER, Agnes. O cotidiano e a história. Rio de Janeiro: Paz e Terra, 1972.

JOST, François. Seis lições sobre televisão. Porto Alegre: Sulina, 2004.

LIPPMAN, Walter. Estereótipos. In: STEINBERG, Ch. (Org.). Meios de comunicação de massa. SP: Cultrix, 1972.

LOPES, Maria Immacolata V. de.; et al. Vivendo com a telenovela: mediações, recepção, teleficcionalidade. São Paulo: Summus, 2002.

MACHADO, Arlindo. A televisão levada a sério. 4. ed. São Paulo: Editora Senac São Paulo, 2005.

MARTÍN-BARBERO, Jesús. Dos meios às mediações: comunicação, cultura e hegemonia. Rio de Janeiro: UFRJ, 1997.

MUNGIOLI, Maria Cristina Palma. Minissérie grande sertão: veredas: gêneros e temas construindo um sentido identitário de nação. Tese de doutorado. Escola de Comunicação e Artes de São Paulo. São Paulo, 2006. 
ROSÁRIO, Nísia Martins do. Formatos e gêneros em corpos eletrônicos. In: DUARTE, Elizabeth Bastos; CASTRO, Maria Lília Dias de. (Orgs.). Comunicação audiovidual: gêneros e formatos. Porto Alegre: Sulina, 2007.

TELEDRAMATURGIA. Disponível em: <http://www.teledramaturgia.com.br/perez.htm>. Acesso em: 3 de dez. 2009.

TODOROV, Tzvetan. Os gêneros do discurso. São Paulo: Martins Fontes, 1980. 